\title{
POSITIVE EFFECT OF ENTEROSORPTION IN DOXORUBICIN-INDUCED CARDIOHEMODYNAMICS ALTERATION
}

\author{
*0.O. Shevchuk', G.V. Portnichenko², T.Y. Lapikova-Bryginska², \\ S.V. Goncharov' ${ }^{2}$, V.G. Nikolaev ${ }^{3}$, V.E. Dosenko² \\ 1 - I. HORBACHEVSKY TERNOPIL NATIONAL MEDICAL UNIVERSITY, TERNOPIL, UKRAINE. \\ 2 - O.O. BOGOMOLETZ INSTITUTE OF PHYSIOLOGY OF THE NATIONAL ACADEMY OF SCIENCE \\ OF UKRAINE, KYIV, UKRAINE. \\ 3 - R.E. KAVETSKY INSTITUTE OF EXPERIMENTAL PATHOLOGY, ONCOLOGY AND RADIOBIOLOGY \\ OF THE NATIONAL ACADEMY OF SCIENCE OF UKRAINE, KYIV, UKRAINE.
}

Background. Anthracycline antibiotics are one of the most effective anti-cancer drugs, but their cardiotoxicity what limits its therapeutic use.

Objective. To analyze the efficiency of enterosorption in doxorubicin-induced cardiohemodynamics violation.

Methods. Subchronic doxorubicin toxicity was modeled by injecting the anthracycline antibiotic intraperitoneally at a dose of $5 \mathrm{mg} / \mathrm{kg}$ once a week for 4 weeks, in total $20 \mathrm{mg} / \mathrm{kg}$. Male Wistar rats were randomly distributed into 3 groups: control; DOX-group and DOX + enterosorbent C2 rats $\left(y=0.18 \mathrm{~g} / \mathrm{cm}^{3}, B E T\right.$ area $\left.2162 \mathrm{~m}^{2} / \mathrm{g}\right)$. Cardiohemodynamics was studied by the Millar Instruments, heart morphometry - by Avtandilov's method.

Results. Mortality rate in DOX-group was 25\%. Ejection fraction and Stroke work indices were lower compared to the control group, preload adjusted maximal power decreased by 57.6\%, minimum volume and end-systolic volume increased by 76,2 and $67.5 \%$ respectively. End-systolic stiffness of left ventricle $\left(E_{\text {max }}\right)$ as well as arterial elastance $\left(E_{d}\right)$ and end-systolic pressure had tended to decrease. Indices of left ventricle (LV) volume at systole increased: V@dPdt $t_{\max }$ - by 73.3\%,v@dPdt $t_{\min }$ - by 81.9\%. End-diastolic volume increased by 54.6\%. As for the $d P d t_{\text {min' }}$ and Tau constant we observed the slight tendency to its decline. Endocardial surface of LV increased by 42.7\%, Planimetric Index - by $40.4 \%$ compared to the control group of rats.

In DOX $+C 2$ group mortality rate was $18.75 \%$. We observed the strong tendency to normalization of the main indices compared to the DOX group and shrinking of the LV. We want to underline the positive trends especially in Ejection Fraction (from $39.62 \pm 10.50 \%$ to $46.23 \pm 11.46 \%$ ) and Stroke Work (from 6406.50 23345.83 to $10363.14 \pm 7329.55 \mathrm{mmHg} \times u \mathrm{~L}$ ) as important indicators of the effectiveness of cardiac pump function.

Conclusions. Enterosorption demonstrated positive impact on the doxorubicin-induced violated cardiohemodynamics and decreased the mortality rate. It is a ground for further investigations.

KEY WORDS: doxorubicin-induced subchronic toxicity; heart damage; enterosorption; cardiohemodynamics parameters.

\section{Introduction}

Anthracycline antibiotics are widely used to treat many types of malignancies because of their high efficacy. But, also, they are cardiotoxic, what limits their therapeutic use and cumulative dose $[1,2]$. Doxorubicin (Adriamycin, a derivative of rubomycin -14-hydrorubomycin) is a part of chemotherapy schemes for treatment of breast and prostate cancer, solid tumors in children, sarcomas, and others. Multiple mechanisms of heart damage by anthracyclines are recognized. Oxidative stress and generation of reactive oxygen species (ROS) by "anthracycline-iron" *Corresponding author. Oksana Shevchuk, associate professor, Pharmacology and Clinical Pharmacology Department, I. Horbachevsky Ternopil National Medical University, Maidan Voli, 1, Ternopil 46001, Ukraine.

E-mail: shevchukoo@tdmu.edu.ua complex; cardiac muscle's accumulation of highly reactive alcoholic metabolite doxorubicinol (DOXol); cytokines disturbances; as a consequence of endogenic intoxication and bacterial translocation because of mucositis are only a few possible ways of cardiomyocytes injury [3-7].

Till today there are no definite and 100\% efficient methods for prevention and treatment of anthracyclines-induced cardiotoxicity. Ironchelating agent dexrazoxane was implemented into protocols based on its capability to prevent free radical release $[8,9]$. But there are some facts that this agent could decrease the efficacy of anti-cancer chemotherapy [10]. That is why the search of effective means to ameliorate the cardiotoxicity of anthracyclines, which do not 
attenuate the anti-tumor activity of drugs, remains actual. Sorption Detoxification is a wellknown method for cleaning of body fluids from toxic endogenous or exogenous compounds. The most widely used types of this method are the purification of blood or its components (hemosorption), oral administration of sorption materials (enterosorption), and applicationsorption therapy of wounds and burns [11]. Our previous studies with enterosorbents Carboline and carbon granular oral adsorbent C2 demonstrated promising results to alleviate the side effects caused by cytostatic agents melphalan and cisplatin (bone marrow suppression, gastrointestinal toxicity, testes damage, etc.) [12-15]. Enterosorbent C2, which has optimized and shifted to mesopores porous structure, in combination with an officinal biosimilar of granulocyte colony-stimulating factor (filgrastim) ameliorated hematologic toxicity and oxidative stress indexes much better than each of these preparations alone [16].

The objective of this study is the assessment of the capability of carbon granular oral adsorbent C2 to diminish the doxorubicininduced heart damage.

\section{Methods}

Materials

Doxorubicin hydrochloride (Doxorubicin Teva $10 \mathrm{mg} / 5 \mathrm{ml}$, concentrate for solution for infusion, TEVA Pharmachemie, the Netherlands) was used for experiments. Carbon oral adsorbent C2 was specially designed at the Department of Means and Methods of Sorption Therapy of R.E. Kavetsky Institute of Experimental Pathology, Oncology and Radiobiology (IEPOR). Parameters of enterosorbent C2 are next: bulk density $y=0.18 \mathrm{~g} / \mathrm{cm}^{3}$, granules with a diameter of $0.15-0.25 \mathrm{~mm}$, the porous structure of C2 is well developed and shifted toward mesopores, which surface is $565 \mathrm{~m}^{2} / \mathrm{g}$. BET (BrunauerEmmett-Teller) surface area is $2162 \mathrm{~m}^{2} / \mathrm{g}$.

\section{Animal studies}

All experiments were carried out with male Wistar rats, $180-220 \mathrm{~g}$ of primary weight, which were reared at TNMU animal facility (Ternopil, Ukraine). All procedures were done according to the local bioethical committee guidelines which conform to the rules and requirements of European Convention for the Protection of Vertebrate Animals Used for Experimental and Other Scientific Purposes (1986) and EU Directive on the Use of Animals for Research Directive 2010/63/EU. A common light-dark cycle was maintained for rats and fed on common rodent chow diet with tap water ad libitum, according to the guidelines for animal care.

A well-documented regimen was used for the induction of heart damage by doxorubicin [17]. Animals were randomly assigned to 3 groups: 1) control group ( $n=7) ; 2)$ rats treated with DOX (DOX-group) $(\mathrm{n}=16) ; 3)$ rats treated with both DOX and carbon enterosorbent C2 $(\mathrm{DOX}+\mathrm{C2})(\mathrm{n}=16)$.

Subchronic doxorubicin toxicity was modeled by injecting the anthracycline antibiotic intraperitoneally at a dose of $5 \mathrm{mg} / \mathrm{kg}$ once a week for 4 weeks, in total $20 \mathrm{mg} / \mathrm{kg}$ [17]. The animals serving as control received the same volume of saline intraperitoneally once a week for a total of 4 weeks. Newly designed carbon oral adsorbent C2 was given into the stomach via a custom rigid tube once a day at a dose of $5 \mathrm{ml}$ per $\mathrm{kg}$ (or $1 \mathrm{ml}$ for each $200 \mathrm{~g}$ of rat body weight; or $900 \mathrm{mg}$ of the dry mass of the enterosorbent). We started enteral sorption therapy the next day after the first injection of Doxorubicin. The sorbent was given as a suspension in an appropriate volume of distilled water. The rats of the control group received an equal volume of distill water. On the days of doxorubicin injection and one day before it, the enterosorbent was not given to avoid any pharmacokinetics disruption.

\section{Cardiohemodynamics measurements}

For the direct cardiac function evaluation, we used Millar pressure-volume (P-V) system (MPVS-300, Millar Instruments, Houston, TX, USA). On the $29^{\text {th }}$ day of the experiment counting from the first injection of doxorubicin, under urethane general anesthesia $(1.5 \mathrm{~g} / \mathrm{kg})$ the right carotid artery was exposed and ligated distally, the artery was clamped and incised, and a $0.5 \mathrm{~cm}$ long $90 \mathrm{PE}$ tube was inserted as a catheter guide. A 2-Fr Mikro-Tip catheter (SPR838, Millar Instruments, Houston, TX, USA) was advanced through the guide into the LV under pressure control; a ligature was then tightened around the catheter to avoid blood loss [18]. After stabilization for 5 min, signals were continuously sampled at a sampling rate of 1000 samples/sec by the MPVS-300 system, recorded, and displayed on a personal computer by the PowerLab System and ChartTM v.5.4.2 software (ADInstruments, Millar Instruments) for 15-20 min.

The relation of pressure and volume of the left ventricle was performed by software PVAN 3.6 (AD Instruments, Millar Instruments) with the conversion of relative volume units (RVU) into absolute one (equation slope 20,25×RVU - 
intercept 29,05). The Millar P-V System simultaneously and continuously measures left ventricle (LV) pressure (P) and volume (V) from the beating heart, producing characteristic PV loops readings of which a variety of cardiovascular parameters, such as heart rate (HR), cardiac output (CO), stroke volume (SV), ejection fraction (EF), stroke work $(\mathrm{SW}), \mathrm{d} P / \mathrm{d} t_{\text {max }}$ and $\mathrm{d} P / \mathrm{d} t_{\text {min }}$ are derived. End-systolic pressure (ESP), end-systolic volume (ESV), end-diastolic pressure (EDP), end-diastolic volume (EDV), stroke volume (SV), stroke work (SW), maximum $\mathrm{d} P / \mathrm{d} t\left(\mathrm{dPdt}_{\max }\right)$, minimum $\mathrm{d} P / \mathrm{dt}\left(\mathrm{d} P \mathrm{~d} t_{\min }\right)$, tau, maximum $\mathrm{d} V / \mathrm{d} t\left(\mathrm{~d} V \mathrm{~d} t_{\max }\right)$, minimum $\mathrm{d} V / \mathrm{d} t$ $\left(\mathrm{d} V \mathrm{~d} t_{\text {min }}\right)$, maximum pressure (Pmax), minimum pressure ( $P$ min), maximum volume (Vmax), and minimum volume ( $V \mathrm{~min})$ were also analyzed.

\section{Morphometrics of the heart}

To estimate chronic changes of the shape and size, the hearts of the rats were used for measuring and evaluating of the planimetric index. For indirect planimetry of the endocardial surface of the rats' hearts, ventricles were taken accordingly to Avtandilov G.G. method[19] in Esypova I.K. et al. modification [20]. We measured the endocardial surfaces of the left $\left(E_{L V}\right)$ and right ventriculi's wall area $\left(\mathrm{E}_{\mathrm{RV}}\right)$. Planimetric index (PI) was calculated as:

$$
P I=E_{L V} \div E_{R V} \text {. }
$$

where $E_{L V}$ is the endocardial surfaces of the left ventricle wall area and $\mathrm{E}_{\mathrm{RV}}$ is the endocardial surfaces of the right ventricle wall area.

\section{Statistical analysis}

The normality of data distribution was tested using Kolmogorov-Smirnov test, homogeneity of variance - Levene's test. MannWhitney test and One-way ANOVA was applied to test the differences between the groups. Statistical analysis was performed using Microsoft Excel XP (USA) and Statistica 10.0 (StatSoft Inc., USA). Differences were considered significant if the probability of Type I error was less than 0.05. $\mathrm{P}<0.05$ was considered significant.

\section{Results}

In DOX-group the number of prematurely deceased rats was four, in DOX+C2 group three rats died before the end of the experiment. All abovementioned animals died after the $4^{\text {th }}$ injection of doxorubicin during the last week of the experiment. Among survived rats we observed typical clinical signs of heart failure: rats showed clear signs of dyspnea, from mild to severe ascites, different stages of hydrothorax and liver enlargement; their common activities were reduced compared to the rats of the control group. Those sings had less intensity compared to the untreated group of animals.

The pump function of the heart was analyzed by next parameters: ejection fraction, stroke volume and stroke work and cardiac output, as well as maximal power and preload adjusted maximal power (PaMP) (table 1). These parameters are load-dependent and consequently represent poor contractility indices. Increased cardiac output, high heart rate as well as stroke volume are the typical signs of cardiac dysfunction and followed systemic hemodynamic changes and our results supposed it. It was a strong tendency for increasing of the all abovementioned indices, but enteral sorption therapy partly disrupts it. Ejection fraction in DOX-group rats was lower, but in the group $\mathrm{DOX}+\mathrm{C2}$, we see the tendency to its normalization. The same tendency was for the stroke work: from $6406.50 \pm 3345.83$ in rats, which received injections of doxorubicin, it increased to $10363.14 \pm 7329.55 \mathrm{mmHg} \times \mathrm{uL}$ for rats which got oral adsorbent concomitantly. While the index in rats of the control group was 7036.43 $\pm 5036.46 \mathrm{mmHg} \times \mathrm{uL}$.

Minimum volume increased by $76,2 \%$, endsystolic volume - by $67.5 \%$. For both indices, we observed the tendency for decreasing by oral adsorbent therapy, but they did not come close to the numbers of control group rats.

In the rats of DOX-group the index of maximal power did not change significantly, but the strong tendency to its decreasing we saw, while preload adjusted maximal power (PaMP) was lower by $57.6 \%$ compared to the control group. Enteral sorption therapy promoted the tendency to normalization of the indices. End-systolic stiffness of left ventricle $\left(\mathrm{E}_{\max }\right)$ had a strong tendency to decreasing from $4.55 \pm 2.93$ to $2.74 \pm 2.02$ (what means that left ventricle was dilated and lost end-systolic elastance), while carbon oral adsorbent C2 increased this index to $5.30 \pm 0.44$.

Specific parameters as the volume at the point of maximal speed of pressure change (V@dPdt ${ }_{\text {max }}$ ) and volume at the point of maximal speed of pressure decline (V@dPdt ${ }_{\text {min }}$ ) are used for assessment of LV volume at systole.

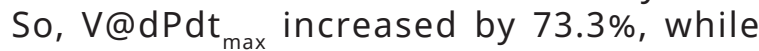
V@dPdt ${ }_{\min }$ - by $81.9 \%$.

During diastole, the myocardium stops shortening and generating force and relaxes. Diastolic function was analyzed by changes of end-diastolic pressure and volume, the peak rate of pressure decline $\left(\mathrm{dPdt}_{\min }\right)$ - isovolumic relaxation, constant Tau by Weiss method $\left(\tau_{w}\right)$. 
Table 1. Cardio-hemodynamics indices in rats, which received doxorubicin and enteral sorption therapy with oral carbon adsorbent $\mathbf{C 2}$.

\begin{tabular}{|c|c|c|c|}
\hline Index & Control group & DOX group & $\mathrm{DOX}+\mathrm{C} 2$ group \\
\hline HR $\left(\min ^{-1}\right)$ heart rate & $321.0 \pm 43.89$ & $356.64 \pm 48.82$ & $378.38 \pm 33.86$ \\
\hline Maximum Volume (uL) & $146.79 \pm 13.08$ & $232.76 \pm 76.58$ & $236.68 \pm 102.07$ \\
\hline Minimum Volume (uL) & $78.27 \pm 15.17$ & $137.93 \pm 46.96 *$ & $126.05 \pm 35.68$ \\
\hline End-systolic Volume (uL) & $84.87 \pm 17.73$ & $142.16 \pm 47.56 *$ & $130.76 \pm 36.68$ \\
\hline End-diastolic Volume (uL) & $142.56 \pm 11.36$ & $220.44 \pm 70.94 *$ & $223.75 \pm 85.04$ \\
\hline Maximum Pressure $(\mathrm{mmHg})$ & $116.24 \pm 21.53$ & $102.0 \pm 22.51$ & $111.85 \pm 14.35$ \\
\hline Minimum Pressure (mmHg) & $4.97 \pm 3.89$ & $4.15 \pm 3.39$ & $2.10 \pm 1.65$ \\
\hline End-systolic Pressure (mmHg) & $109.57 \pm 25.12$ & $96.22 \pm 24.07$ & $104.58 \pm 16.72$ \\
\hline End-diastolic Pressure $(\mathrm{mmHg})$ & $9.10 \pm 4.28$ & $6.72 \pm 4.54$ & $5.99 \pm 3.77$ \\
\hline Stroke Volume (uL) & $68.52 \pm 21.34$ & $94.835 \pm 39.90$ & $120.88 \pm 78.45$ \\
\hline Ejection Fraction (\%) & $46.15 \pm 11.83$ & $39.62 \pm 10.50$ & $46.23 \pm 11.46$ \\
\hline Cardiac Output (uL/min) & $22222.85 \pm 8424.99$ & $33103.55 \pm 13814.04$ & $44721.45 \pm 28511.89$ \\
\hline Stroke Work (mmHg×uL) & $7036.43 \pm 5036.46$ & $6406.50 \pm 3345.83$ & $10363.14 \pm 7329.55$ \\
\hline Arterial Elastance (Ea), (mmHg/uL) & $2.25 \pm 0.71$ & $1.06 \pm 0.49$ & $1.11 \pm 0.56$ \\
\hline $\mathrm{dPdt} \max (\mathrm{mmHg} / \mathrm{sec})$ & $11758.0 \pm 5232.28$ & $9897.43 \pm 3142.76$ & $12769.50 \pm 2861.17$ \\
\hline $\mathrm{dPdt} \min (\mathrm{mmHg} / \mathrm{sec})$ & $-7312.86 \pm 2477.79$ & $-7062.50 \pm 1742.62$ & $-8928.12 \pm 3274.57$ \\
\hline $\mathrm{dVdt} \max (\mathrm{uL} / \mathrm{sec})$ & $2811.14 \pm 1048.07$ & $4783.57 \pm 1703.76$ & $4489.87 \pm 2985.50$ \\
\hline $\mathrm{dVdt} \min (\mathrm{uL} / \mathrm{sec})$ & $-3345.57 \pm 1283.04$ & $-3893.5 \pm 1345.52$ & $-4751.13 \pm 2491.48$ \\
\hline $\mathrm{P@dVdt} \mathrm{max} \mathrm{(mmHg)}$ & $38.27 \pm 32.11$ & $40.16 \pm 35.79$ & $34.62 \pm 36.27$ \\
\hline P@dPdt min (mmHg) & $88.67 \pm 50.41$ & $64.69 \pm 13.78$ & $74.00 \pm 21.68$ \\
\hline V@dPdt max (uL) & $124.90 \pm 25.62$ & $216.46 \pm 76.45 *$ & $228.02 \pm 102.85 *$ \\
\hline V@dPdt min (uL) & $79.91 \pm 15.49$ & $145.33 \pm 52.64 *$ & $129.76 \pm 36.71$ \\
\hline $\operatorname{Tau}(\mathrm{W})$ (msec) & $12.69 \pm 5.87$ & $11.41 \pm 5.01$ & $9.25 \pm 1.96$ \\
\hline $\operatorname{Tau}(\mathrm{G})(\mathrm{msec})$ & $18.34 \pm 11.18$ & $13.80 \pm 5.68$ & $11.90 \pm 3.39$ \\
\hline Maximal Power (mWatts) & $43.89 \pm 34.61$ & $38.94 \pm 18.71$ & $57.61 \pm 32.30$ \\
\hline $\begin{array}{l}\text { Preload adjusted maximal power, } \\
\left.\text { PaMP (mWatts } / \mu L^{\wedge} 2\right)\end{array}$ & $20.81 \pm 15.88$ & $8.82 \pm 4.78 *$ & $12.38 \pm 5.77$ \\
\hline$E_{\max }$ & $4.55 \pm 2.93$ & $2.74 \pm 2.02$ & $5.30 \pm 0.44$ \\
\hline
\end{tabular}

Notes. The data are expressed as means $(M) \pm$ standard deviation (SD); $*-p<0,05$ comparing to control group; $d P d t_{\text {max }}-p e a k$ rate of pressure rise; $d P d t_{\min }$ - peak rate of pressure decline; $d V d t_{\max }$ - peak rate of volume rise; $d V d t_{\min }$ - peak rate of volume decline; P@dVdt $t_{\max }$ - Pressure at dV/dt max; P@dPdt $t_{\min }-$ Pressure at $d V / d t_{\min } ; @ @ d P d t_{\max }-V o l u m e a t d P / d t_{\max } ; @ @ d P / d t_{\min }-$ Volume at $d P / d t_{\text {min }}$; Tau $(G)$ - relaxation time constant calculated by Glantz method (regression of $d P / d t$ versus pressure); Tau (W) - relaxation time constant calculated by Weiss method (regression of log(pressure)); $E_{\max }$ - end-systolic elastance.

End-diastolic volume increased by $54.6 \%$ in the group of rats, which received doxorubicin compared to the control rats. As for the $\mathrm{dPdt}_{\min }$ we observed a slight tendency to its decline, as well as for the Tau constant.

After 4 injections of Doxorubicin on $29^{\text {th }}$ day of the experiment, the endocardial surface of the left ventricular wall area increased by $42.7 \%$ $(p<0.001)$ compared to control group of rats (table 2). At the same time, there were no changes in the right ventricular wall area. In rats which received enterosorption together with doxorubicin, the endocardial surface of the left ventricular wall area index decreased

Table 2. The influence of enterosorption on morphometric indexes of the heart ventricles in subchronic doxorubicin toxicity in rats.

\begin{tabular}{|l|c|c|c|}
\hline \multicolumn{1}{|c|}{ Index } & Control group & DOX-group & DOX+C2 group \\
\hline $\begin{array}{l}\text { The endocardial surface of left ventricular } \\
\text { wall area, } \mathrm{mm}^{2}\end{array}$ & $118.0 \pm 4.45$ & $168.4 \pm 7.63 *$ & $132.6 \pm 3.06 *, \star *$ \\
\hline $\begin{array}{l}\text { The endocardial surface of right ventricular } \\
\text { wall area, } \mathrm{mm}^{2}\end{array}$ & $132.2 \pm 6.27$ & $134.8 \pm 6.54$ & $137.8 \pm 4.88$ \\
\hline Planimetric index (PI) & $0.894 \pm 0.010$ & $1.25 \pm 0.032 *$ & $0.965 \pm 0.022^{\star *}$ \\
\hline
\end{tabular}

Notes: The data are expressed as means $(M) \pm$ standard error (SE). $p<0.05$ compared to * - control group; ** - DOX-group. 
by $21.3 \%$ compared to the DOX group, but it was still larger than in rats of the control group.

Doxorubicin injections increased the Planimetric index (PI) the by $40.4 \%$ compared to the control group (from $0.89 \pm 0.01$ to $1.25 \pm 0.03$ ), while in $\mathrm{DOX}+\mathrm{C} 2$ group it decreased by $22.8 \%$ $(0.96 \pm 0,02, p<0.001)$.

\section{Discussion}

Our study deals with the effect of enterosorption on doxorubicin-associated cardiac toxicity. Doxorubicin's use in patients is limited by its cardiac toxicity. Today a new subspecialty appeared - cardio-oncology, which focuses on prevention, detection, monitoring, and treat ment of cardiovascular pathology during anticancer chemotherapy [21]. It is a marker of the high importance of this problem because long term survival of childhood cancers is more than $70 \%$ for now [6] and continued to increase [22]. Strong links between cancer and heart disease are recognized, that is why a clinical need for optimized cardio-oncology patient management is growing. Among anti-cancer agents, the most capable drugs to cause the dilative cardiomyopathy are anthracyclines and cyclophosphamide [16,23]. Dose-dependent irreversible heart damage occurs in $1.7 \%$ of patients mostly via oxidative stress activation and by inhibition of transcriptions of genes, which are responsible for the synthesis of the contractile proteins $[3,16]$. Up to $3 \%$ of heart transplantations were done for patients because of doxorubicin therapy [6]. It is known that the prognosis of patients who develop doxorubicin-induced congestive heart failure is poor: approximately $\sim 50 \%$ mortality in 1 year [3]. Monoclonal antibody trastuzumab and low molecular tyrosine kinase inhibitors as sunitinib and sorafenib may cause heart damage too [23]. They modulate mitochondrial integrity, deplete ATP and lead to contractile dysfunction. But in this case, the contractile function of the left ventricle improves after drugs discontinuation [23].

We used typical widespread modeling to induce congestive heart failure in rats: four injections of DOX at the dose of $5 \mathrm{mg} / \mathrm{kg}$ for cumulative dose $20 \mathrm{mg} / \mathrm{kg}$ and got the cardiohemodynamic disruption [17]. So, this model could be used for assessment of the capability of different substances and drugs to impact the heart systolic and diastolic function. One of the experimental morphometric methods to measure and estimate the type and deepness of heart injury is weighing and weight measurement of different parts of the organ namely left and right ventricle with the septum (ventricle index, Fulton index, etc.). The planimetric method allows estimating changes of both ventricles by measuring the endocardial surfaces area [19]. And this method is validated to estimate the chronic changes of the heart morphology, while cardiohemodynamics violations measured by Millar Instruments are quite good for assessment of acute functional changes in heart work.

A wide variety of indexes that can be quantified by analyzing pressure-volume (PV) loops have been proposed to characterize the left ventricle systolic and diastolic performance. In the present study, doxorubicin-associated cardiac dysfunction was manifested by a reduction in cardiac systolic and diastolic hemodynamic function. We have shown statistically significant differences between DOX and control groups in parameters of end-systolic and end-diastolic volumes as well as volumes at the point of maximal speed of pressure change and pressure decrease. Also, we have shown a $57.6 \%$ decrease in Preload adjusted maximal power. Doxorubicin at the cumulative dose of $20 \mathrm{mg}$ per $\mathrm{kg}$ promoted the heart dilation, which was confirmed by increased indices of the endocardial surface of the left ventricular wall area and planimetric index. Our previous study demonstrated the decreased mass of the heart in subchronic doxorubicin toxicity. So, despite only the slight tendency of ejection fraction declining, these important changes already indicate the onset of the dilated cardiomyopathy. Such results are supported by research on the male New Zealand white rabbits with doxorubicin-induced heart damage [24]. So, we may conclude, that early myocardial effects of doxorubicin-induced cardiotoxicity are presented. We may talk about early stages of dilated cardiomyopathy with still preserved ejection fraction, but with clinical signs of congestion in survived rats - non-failing dilated left ventricle in survived animals. Our results are confirmed by the study of Lodi M. et al. [25]: A significantly reduced ejection fraction was seen on day 80 only. They modeled cardiomyopathy by 6 IV injection of DOX at the dose of $1.5 \mathrm{mg} / \mathrm{kg}$ on the $8^{\text {th }}, 11^{\text {th }}, 14^{\text {th }}, 17^{\text {th }}, 20^{\text {th }}$ and $23^{\text {rd }}$ days of the experiment [25]. Also, the results of our histological examination of heart tissues presented revealed loss of myofibrils and striations, as well as cytoplasmic edema.

Our previous study demonstrated that enterosorption with C2 ameliorates the morphological sings of heart damage [26]. Also, we 
observed improvements of hematological parameters, kidney's function and decrease of endogenous intoxication markers. Those data are in press.

It is important to mention that the concomitant course of enterosorption during this experiment decreased the mortality rate. In rats which received doxorubicin, it was $25 \%$ (4 rats from 16$)$, while at the DOX+C2 group $-18.75 \%$ (3 rats from 16).

$\mathrm{DOX}+\mathrm{C} 2$ rats' group has shown a statistically significant difference compared to the control group in the parameter of volume at the point of maximal speed of pressure change. V@dPdt increased by $82.6 \%$.

All 26 parameters of cardiohemodynamics were altered in rats which received doxorubicin at the total dose of $20 \mathrm{mg} / \mathrm{kg}$. More than a half (14 parameters) among them demonstrated tendency to normalization under the influence of enteral sorption therapy. Especially we want to notice the positive tendency in indices of Preload adjusted maximal power, PaMP (from $8.82 \pm 4.78$ to $12.38 \pm 5.77 \mathrm{mWatts} / \mu \mathrm{L} \wedge 2$ ), Maximal Power (from $38.94 \pm 18.71$ to $57.61 \pm 32.30$ mWatts, and it was even higher than in the control group - 43.89 \pm 34.61 mWatts), Stroke Work (from $6406.50 \pm 3345.83$ to $10363.14 \pm 7329.55$ $\mathrm{mmHg} \times \mathrm{uL}$, while the control group index was $7036.43 \pm 5036.46 \mathrm{mmHg} \times \mathrm{uL}$ ) and Ejection Fraction from $39.62 \pm 10.50 \%$ to $46.23 \pm 11.46 \%$, when in the control group it was $46.15 \pm 11.83 \%$ ).

\section{Conclusions}

Doxorubicin at the total dose of $20 \mathrm{mg} / \mathrm{kg}$ caused pronounced violation of cardiohemodynamics. Systolic indices as Ejection fraction, stroke work, end-systolic elastance $\left(\mathrm{E}_{\max }\right)$, endsystolic pressure - all these indices demonstrated a tendency to decline, preload adjusted maxi mal power (PaMP) was lower by $57.6 \%$ compared to the control group. It is a marker of weaker pump function and poor contractility of the heart. Morphometry showed dilation of the left ventricle and increased planimetric index. At the same time, the diastolic indices were disrupted too. End-diastolic volume significantly increased by $54.6 \%$, the index of peak rate of pressure had a tendency for declining, as well as Tau(w). The indices of volume at the point of maximal speed of pressure change (V@dPdt ${ }_{\text {max }}$ ) and volume at the point of maximal speed of pressure decline (V@dPdt ${ }_{\text {min }}$ ) significantly increased in rats, which received doxorubicin. It confirms the diastolic dysfunction presence.

Enteral sorption therapy mostly normalized and improved violated indices and decreased the rate mortality of rats. We observed shrinking of the endocardial surface of the left ventricular wall area by $21.3 \%$ and decreasing of Planimetric Index. Those results demonstrate that enterosorption could prevent remodeling of the heart chambers. Our cardiohemodynamics investigations included more than 20 parameters and though mostly they are not statistically significant we want to underline the positive trends in $\mathrm{DOX}+\mathrm{C} 2$ rats comparing to DOX-group, especially in Ejection Fraction and Stroke Work parameters as they are the important indicators of the effectiveness of cardiac pump function. Such results could be explained by the fact that measurement of hemodynamics was done one week later after the last 4th injection of doxorubicin, and we observed the consequences of mechanisms of adaptation in survived rats.

Our research demonstrated promising results of the efficiency of carbon granular oral adsorbent C2 to ameliorate the doxorubicinassociated cardiohemodynamics changes and are the ground for further future investigation of different combinations of enterosorption and cardio-tropic drugs.

\section{Funding}

This research received no external funding.

\section{Conflict of Interests}

The authors declare no conflict of interest.

\section{Author Contributions}

Shevchuk 0.O. - investigation, conceptualization, resourses, writing - original draft; Portnichenko G.V. - formal analysis, visualization, investigation, writing - original draft, data curation, Lapikova-Bryginska T.Y. - investigation, data curation, Goncharov S.V. - investigation, data curation; Nikolaev V.G. - conceptualization, project administration, writing (review and editing), supervision; Dosenko V.E. - project administration, writing (review and editing), supervision. 


\title{
ПОЗИТИВНИЙ ВПЛИВ ЕНТЕРОСОРБЦІї НА ПОРУШЕННЯ КАРДІОГЕМОДИНАМІКИ, СПРИЧИНЕНІ ДОКСОРУБІЦИНОМ
}

\author{
О.О. Шевчук'1, Г.В. Портніченко ${ }^{2}$, Т.Є. Лапікова-Бригінська², \\ С.В. Гончаров², В.Г. Ніколаєв ${ }^{3}$ В.Є. Досенко \\ 1 - ТЕРНОПІЛЬСЬКИЙ НАЦІОНАЛЬНИЙ МЕДИЧНІ УНІВЕРСИТЕТ ІМЕНІ І.Я. ГОРБАЧЕВСЬКОГО, \\ ТЕРНОПІЛЬ, УКРАЇНА \\ 2 - ІНСТИТУТ ФІЗІОЛОГІЇ ІМЕНІ О.О, БОГОМОЛЬЦЯ НАН УКРАЇНИ, КИЇВ, УКРАЇНА \\ 3 - ІНСТИТУТ ЕКСПЕРИМЕНТАЛЬНОЇ ПАТОЛОГІЇ, ОНКОЛОГІЇ І РАДІОБІОЛОГІЇ ІМЕНІ Р.Є. КАВЕЦЬКОГО \\ НАН УКРАЇНИ, КИЇ̈, УКРАЇНА
}

Вступ. Кардіотоксичність протипухлинних лікарських засобів, і особливо антрациклінових антибіотиків, є одним з лімітуючих факторів ефективного лікування злоякісних новоутворів.

Мета. Дослідити можливості ентеросорбції для пом'якшення кардіогемодинамічних змін, викликаних доксорубіцином в експерименті.

Методи. Субхронічна доксорубіцинова токсичність моделювалася чотирьохкратним введенням доксорубіцину інраперитонеально в дозі 5 мг/кг один раз на тиждень протягом 4 тижнів у сумарній кумулятивній дозі 20 мг/кг. Щури були рандомізовані у з групи: контроль, група тварин, що отримувала доксорубіцин (DOX-група) та групу, котра окрім останнього отримувала ентеросорбент $C 2$ ( $\left(\mathrm{y}=0.18 \mathrm{z} / \mathrm{CM}^{3}\right.$,

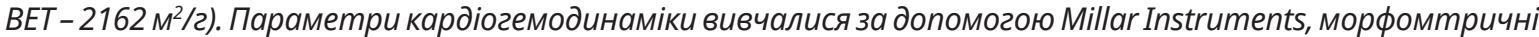
зміни серця - за методом Автанділова.

Результати. Летальність у DОХ-групі склала 25\%. Показники фракції викиду та ударної роботи серця знижувалися порівняно з показниками контрольної групи. Показник максимальної потужності, зрівноваженої на переднавантаження був достовірно нижчим на 57,6\%, а мінімальний об'єм та кінцевосистолічний об'єм зросли на 76,2 та 67,5\%, що свідчить про розвиток застійних явищ. Показники $v @ d P d t_{\max }$ зросли на 73.3\%, v@dPdt $t_{\min }$ - на 81.9\%. Кінцево-діастолічний об'єм був вищим на 54.6\%. Спостерігалася тенденція до зниження $d P d t_{\min }$ ma Таи константи. Ендокардіальна поверхня лівого шлуночка зросла на 42,7\%, а планіметричний індекс - на 40,4\%.

У групі DOX+C2 летальність склала 18,75\%. Спостерігалася виражена тенденція до нормалізації усіх показників. Особливо ми хочемо підкреслити позитивний ефект застосування вуглецевого

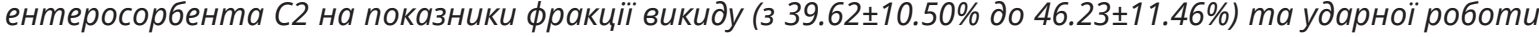

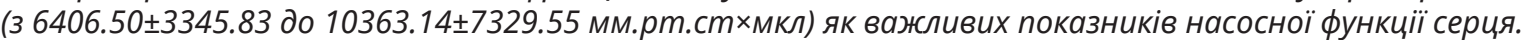

Висновки. В статті наведені дані, котрі демонструють здатність ентеральної сорбційної терапії зменшувати зрушення показників кардіогемодинаміки, спричинені введенням доксорубіцину. Окрім цього, ентеросорбція сприяла зменшенню показника летальності піддослідних тварин.

КЛЮчОВІ СЛОВА: субхронічна доксорубіцинова токсичність; пошкодження серця; ентеросорбція; параметри кардіогемодинаміки.

Відомості про авторів

Шевчук Оксана - канд. мед. наук, доцент кафедри фармакології з клінічною фармакологією, Тернопільський національний медичний університет імені І.Я. Горбачевського, Тернопіль , Україна

Портніченко Георгій - канд. біол. наук, відділ загальної та молекулярної патофізіології, Інститут фізіології імені О.О.Богомольця НАН України, Київ, Україна.

Лапікова-Бригінська Тетяна - відділ загальної та молекулярної патофізіології, Інститут фізіології імені О.О.Богомольця НАН України, Київ, Україна.

Гончаров Сергій - відділ загальної та молекулярної патофізіології, Інститут фізіології імені О.О.Богомольця НАН України, Київ, Україна.

Ніколаєв Володимир Григорович - чл.-кор. НАН України, професор, д-р мед. наук, завідувач відділу засобів та методів сорбційної терапії, Інститут експериментальної патології, онкології і радіобіології імені Р.Є. Кавецького НАН України, Київ, Україна.

Досенко Віктор Євгенович - професор, д-р мед. наук, завідувач відділу загальної та молекулярної патофізіології інституту фізіології імені О.О. Богомольця НАН України, Київ, Україна.

Information about the authors

Oksana O. Shevchuk - MD, Ph.D., Pharmacology and Clinical Pharmacology Department, I. Horbachevsky Ternopil National Medical University, Ternopil, Ukraine.

ORCID 0000-0003-2473-6381, e-mail: shevchukoo@tdmu.edu.ua

Georgii V. Portnichenko - Ph.D., Department of General and Molecular Pathophysiology, Bogomoletz Institute of Physiology of the National Academy of Science of Ukraine, Kyiv, Ukraine.

ORCID 0000-0001-8834-3013, e-mail: krissaegrim1@gmail.com 
Tetiana Y. Lapikova-Bryhinska - Department of General and Molecular Pathophysiology, Bogomoletz Institute of Physiology of the National Academy of Science of Ukraine, Kyiv, Ukraine.

ORCID 0000-0003-3405-6566, e-mail: tlapikovabr@gmail.com

Sergii V. Goncharov - Department of General and Molecular Pathophysiology, Bogomoletz Institute of Physiology of the National Academy of Science of Ukraine, Kyiv, Ukraine.

E-mail: sergei_goncharov@bigmir.net

Volodymyr G. Nikolaev - MD, Ph.D., DSc, professor, Department of Means and Methods of Sorption Therapy, R.E. Kavetsky Institute of Experimental Pathology, Oncology and Radiobiology of the National Academy of Science of Ukraine, Kyiv, Ukraine.

E-mail: aosiepor2@gmail.com

Victor E. Dosenko - MD, Ph.D., DSc, professor, Department of General and Molecular Pathophysiology, Bogomoletz Institute of Physiology of the National Academy of Science of Ukraine, Kyiv, Ukraine.

ORCID 0000-0002-6919-7724, e-mail: dosenko@biph.kiev.ua

\section{References}

1. Jain D, Russell RR, Schwartz RG, Panjrath GS, Aronow W. Cardiac Complications of Cancer Therapy: Pathophysiology, Identification, Prevention, Treatment, and Future Directions. Curr Cardiol Rep 2017;19:36. doi:10.1007/s11886-017-0846-x

2. Linnik O, Drevytska TI, Tarasova K, Portnichenko G, Dosenko VE, Mankovskaya IN. DoxorubicinInduced Disturbances of Cardiomyocyte Contractile Activity. Int J Physiol Pathophysiol 2018;9:9-16.

doi:10.1615/IntJPhysPathophys.v9.i1.20

3. Chatterjee K, Zhang J, Honbo N, Karliner JS. Doxorubicin cardiomyopathy. Cardiology 2010;115: 155-62.

doi:10.1159/000265166

4. Curigliano G, Cardinale D, Dent S, Criscitiello C, Aseyev O, Lenihan D, et al. Cardiotoxicity of Anticancer Treatments : Epidemiology, Detection, and Management. CA Cancer J Clin 2016;66:309-25. doi:10.3322/caac.21341

5. Swain SM, Whaley FS, Ewer MS. Congestive heart failure in patients treated with doxorubicin. Cancer 2003;97:2869-79.

doi:10.1002/cncr.11407

6. Mitry MA, Edwards JG. Doxorubicin induced heart failure: Phenotype and molecular mechanisms. Int J Cardiol Hear Vasc 2016;10:17-24.

doi:10.1016/j.ijcha.2015.11.004

7. Shaul P, Frenkel M, Goldstein EB, Mittelman L, Grunwald A, Ebenstein Y, et al. The structure of anthracycline derivatives determines their subcellular localization and cytotoxic activity. ACS Med Chem Lett 2013;4:323-8.

doi:10.1021/ml3002852

8. Volkova M, Russell R, III. Anthracycline cardiotoxicity: prevalence, pathogenesis and treatment. Curr Cardiol Rev 2011;7:214-20. doi:10.2174/157340311799960645

9. Shevchuk OO, Posokhova EA, Sakhno LA, Nikolaev VG. Theoretical ground for adsorptive therapy of anthracyclines cardiotoxicity. Exp Oncol 2012;34:314-22.
10. Trachtenberg BH, Landy DC, Franco VI, Henkel JM, Pearson EJ, Miller TL, et al. AnthracyclineAssociated Cardiotoxicity in Survivors of Childhood Cancer. Pediatr Cardiol 2011;32:342-53.

doi:10.1007/s00246-010-9878-3

11. Nikolaev VG. Sorption Therapy with the Use of Activated Carbons: Effects on Regeneration of Organs and Tissues. Hemoperfusion, Plasmaperfusion Other Clin. Uses Gen. Biospecific, Immuno Leucoc. Adsorbents, 2017, p. 221-43.

doi:10.1142/9789814749084_0007

12. Shevchuk OO, Posokhova KA, Sidorenko AS, Bardakhivska KI, Maslenny VM, Yushko LA, et al. The influence of enterosorption on some haematological and biochemical indices of the normal rats after single injection of melphalan. Exp Oncol 2014;36:94100.

13. Shevchuk OO, Posokhova KA, Todor IN, Lukianova NY, Nikolaev VG, Chekhun VF. Prevention of myelosuppression by combined treatment with enterosorbent and granulocyte colony-stimulating factor. Exp Oncol 2015:37:135-8.

14. Sakhno LA, Yurchenko OV, Maslenniy VN, Bardakhivskaya KI, Nikolaeva VV, Ivanyuk AA, et al. Enterosorption as a method to decrease the systemic toxicity of cisplatin. Exp Oncol 2013;35:45-52.

15. Shevchuk OO, Bodnar YY, Bardakhivska KI, Datsko T V., Volska AS, Posokhova KA, et al. Enterosorption combined with granulocyte colony stimulating factor decreases melphalan gonadal toxicity. Exp Oncol 2016;38:172-5.

16. Shevchuk OO, Snezhkova EA, Bardakhivskaya KI, Nikolaev VG. Adsorptive Treatment of Acute Radiation Sickness: Past Achievements and New Prospects. Hemoperfusion, Plasmaperfusion Other Clin. Uses Gen. Biospecific, Immuno Leucoc. Adsorbents, vol. 4, 2017, p. 245-56.

doi:10.1142/9789814749084_0008

17. Stefanov O. Preclinical studies of drugs: methodical instructions. Kyiv: Avicenna; 2001. (In Ukrainian). 
18. Pacher $P$, Nagayama $T$, Mukhopadhyay $P$, Bátkai S, Kass DA. Measurement of cardiac function using pressure-volume conductance catheter technique in mice and rats. Nat Protoc 2008;3:1422-34.

doi:10.1038/nprot.2008.138

19. Avtandilov G. Basics of quantitative pathological anatomy. 2nd ed. Moscow: Medicina; 2002. (In Russian).

20. Esypova IK, Aliskevych VI, Purdiaev YS. Method of urgent differential diagnosis of different types of pulmonary hypertension at section table. Sud Meditsinskaia Ekspert 2003:27-30. (In Russian).

21. Kostakou PM, Kouris NT, Kostopoulos VS, Damaskos DS, Olympios CD. Cardio-oncology: a new and developing sector of research and therapy in the field of cardiology. Heart Fail Rev 2018:1-10.

doi:10.1007/s10741-018-9731-y

22. Ward E, Sherman RL, Henley SJ, Jemal A, Siegel DA, Feuer EJ, et al. Annual Report to the Nation on the Status of Cancer, 1999-2015, Featuring Cancer in Men and Women ages 20-49. JNCI J Natl Cancer Inst 2019.

doi:10.1093/jnci/djz106
23. Adão R, De Keulenaer G, Leite-Moreira A, Braś-Silva C. Cardiotoxicity associated with cancer therapy: Pathophysiology and prevention strategies. Rev Port Cardiol 2013;32:395-409.

doi:10.1016/j.repc.2012.11.002

24. Rodrigues PG, Miranda-Silva D, Costa SM, Barros C, Hamdani N, Moura C, et al. Early myocardial changes induced by doxorubicin in the nonfailing dilated ventricle. Am J Physiol Circ Physiol 2018;316: H459-75.

doi:10.1152/ajpheart.00401.2018

25. Lodi M, Priksz D, Fulop GA, Bodi B, Kocsis J, Edes I, et al. Advantages of prophylactic versus conventionally scheduled heart failure therapy in an experimental model of doxorubicin-induced cardiomyopathy. J Transl Med 2019;17:229.

doi:10.1002/ejhf.1197

26. Shevchuk OO, Datsko T V., Posokhova KA, Nikolaev VG. Histological findings at application of newly designed granular carbon enterosorbent under subchronic doxorubicin toxicity in rats. Pharmacol Drug Toxicol 2019;13:119-30.

Received 04 September 2019; revised 09 October 2019; accepted 21 October 2019.

This is open access article distributed under the Creative Commons Attribution License, which permits unrestricted use, distribution, and reproduction in any medium, provided the original work is properly cited. 